\title{
Reading Sign as a response to an architectural work (Case study: Wisma Garuda)
}

\author{
Imam Faisal Pane ${ }^{1}$, Hilma T Fachrudin ${ }^{1}$, Hesti Fibriasari ${ }^{2}$, Aurora S Lubis ${ }^{1}$ \\ ${ }^{1}$ Department of Architecture, Faculty of Engineering, Universitas Sumatera Utara, Medan, Indonesia \\ ${ }^{2}$ Department of Foreign Language, Universitas Negeri Medan, Medan, Indonesia \\ Email:imam.faisal@usu.ac.id
}

\begin{abstract}
Between objects and observers in the world of architecture have a close relationship. In assessing and appreciating an architectural work it is necessary to synchronize architectural objects as a sign. The sign in question means an architectural work that functions as a sentence that can be read and has a meaning or meaning. The position of an architectural work depends on the observer in appreciating it. In general, this paper explains that an architectural object has an understanding that can be understood by the observer in accordance with the appreciation reached to the observer. The object under study was Wisma Garuda, a budget hotel. Where the hotel applies the concept of experience in architecture, but it reads as Buddhist philosophy by the curator of the Indonesian Pavilion 2018. Even though the architect of the building does not use Buddhist philosophy, based on an analysis of the interconnectedness of Husserl's and Buddha's philosophy it proves that the meaning received by the curator is something natural.
\end{abstract}

Keywords: reading; sign; architectural

\section{Introduction}

The task of an architect is to serve clients or meet the needs of the community [1]. In that fulfilment, architects often incorporate the values of Architecture they understand into their designs. In addition to trying to meet the elements of building functionality, it also presents aesthetic value and meaning so that it can be felt and read by visitors or users of the building. Besides that, sometimes architects also try to present the atmosphere that is captured by the senses so that the building's presence can be felt its aesthetic value [2]

In modern architecture, functionality (formfollowfunction) and space efficiency take precedence so forget that humans need sensory stimulation. In addition, modern architecture will shape humans like machines with no experience to feel aesthetics [3]. For example, office buildings only accommodate work activities. People come to work in buildings and when they are finished they return to their homes. The building is made as concise and efficient as possible and forgets the space and other building elements that can provide experience and meaning to the user. Besides that, modern architecture also adheres to universalism so that it cannot be distinguished which are office and hotel buildings, even houses and shops.

In architecture education today, usually an architect accepts architectural theories and basic design that is adequate so that he can solve problems and design for the community. A set of architectural sciences can take the form of problem identification skills, organizational discovery and problem solving, conceptualization, and finally design buildings and the environment. The history of architecture in Indonesia and its education in the last two decades are characterized by modern architecture. Lately, world architecture has developed in a postmodern direction and architects are re-thinking of human values in the design of the building. [4] In the end, office buildings do not merely function as workplaces, hotel buildings are 
not merely temporary resting places, but also can provide experienced and rich children to its visitors.

In the architecture, this term was adopted as Indisch Architecture. This term is also known as the Indische Empire (Handinoto, 1994). During the reign of the Dutch East Indies under General GovernorHerman Willem Daendles (1808-1811) had a major influence on the city of Batavia (Jakarta) and several other cities in Java. The influence which was brought by Daendles was widely applied to buildings built during his reign. At that time the style that developed was the Indischche Empire which took the Empire style from France. Handinoto in pane (2019)

The focus of this research is to describe qualitatively about an architect designing a building with the knowledge he has and seeing the effectiveness of observers' responses, with the case of Wisma Garuda Medan, which is included in a book review in the International Architecture Exhibition of La Biehnale in Venice, Italy. The theme raised by the Indonesian Pavilion curator 2018 is Sunyata: The Poetics of Emptiness [5]. Sunyata itself comes from Sanskrit which is translated into English as emptiness or in Indonesian is emptiness. Sunyata or emptiness is also one of the Buddhist philosophies that describe a person's spiritual condition in taking the Buddha's path. [6] [7]. In an interview with the hotel architect, it was found that the concept used to design is experience. Where visual building, interior space and building elements are planned will provide experience for visitors.

The phenomenon that will be investigated is experience connectivity with emptiness (Buddhist philosophy). Meanwhile, based on interviews, the hotel architect did not intend to explore Buddhist philosophy and apply it in concept. . The question that will be answered is why architects who apply the concept of experience have a place in international scale exhibitions with the theme of Buddhist philosophy, namely emptiness or voidness.

The phenomenon of man-madeplace in which there are also architects, in this era is also a discussion of the genius lociNorberg-Schulz. Where architects design trying to provide experience and meaning for users or observers in a contemporary built environment [8].

\section{Review of Literature}

\subsection{Experience in Architecture}

In an interview with one of the hotel architects, stated that experience is a concept used to design Garuda Guest House. Where the visual building, interior space and building elements will provide experience for visitors.

Rasmussen in his book stated that architecture should provide experience, both pleasant experiences and special experiences to the observer or user. The experience is presented by building objects and their elements in the form of space and shape, color, scale and proportion, rhythm, texture, lighting, and sound system [9]. Experience philosophy study is a study of psychological phenomenology and human perception. Experience is knowledge gained and remembered or mastery of an event both from other subjects as well as objects and environments in their interaction involvement. Human experience is related to the ability of physical cognition, mental, emotional, spiritual, social, simulation and individual perception. But the philosophy is how mental consciousness and unconsciousness of humans carry out cognitive processes [10]. Cognitive mental is formed because the human senses receive things from the outside and then processed by the mind, emotions and memories, with the final result of mental perception [11]. 
Art is a product of the experience of human interaction with the environment and architecture is also an important example of this reciprocal relationship. Thought experience in architecture is based on the philosophies of Edmund Husserl, Martin Heidegger, Maurice Merleau-Ponty, GastonBachelard and many other contemporary philosophers. While its application in architecture was introduced by SteenEileer Rasussen, Christian Norberg-Schulz, Charles Moore, David Seamon, Robert Murerauer, and Karsten Harries [12].

\subsection{Buddhist philosophy}

In Buddha, a person can have the highest consciousness or more commonly referred to as consciousness by passing through the stage of emptiness (sunyata). Emptiness is a condition in which a person can spiritually attain freedom from lust that was previously in doubt (ambiguity) or a state of emptying one's self from lust that is manifested in the mind and body so that the mind can concentrate on becoming clearer and stronger [13]. In emptiness architecture this can be manifested in the form of empty space or empty space [14]. While lines that represent shapes will be able to present images that are not drawn or voidspace. In fact, the absence or absence of these walls will illustrate the effects of lighting and shading in the space [15].

According to Cohen, a person is in a state of consciousness if he has passed the stage of emptiness will get enlightment [16]. Spiritual training to gain consciousness in traditional Japanese social culture is at the tea ceremony. Fragrant tea, concentration of the mind, the order of the ceremony, the placement of flowers in an empty space, the rough tatami texture, the elements in the room and the equipment for drinking tea, provide the experience of awareness of the five senses, thoughts, emotions and memories [17].

Emptiness or emptiness in architecture has several criteria that can move the quality of the senses of consciousness, namely as follows: (a) light, (b) texture, (c) sound, and (d) tendency to use the place or space is not just a form, but to form a place [18].

In this case emptiness is manifested into a space in a building where this building provides communication to the observer. The world of architecture has a theory that can explain how buildings can communicate, namely Architectural Semiotics.

\section{Research Methods}

In this research the method used is descriptive qualitative. Analysis of field facts uses phenomenological-based experience theories. Qualitative methods using inductive approaches and facts in the field used as research objects will be able to be investigated and analyzed more comprehensively [19] [20].

The object of research will be focused on Wisma Garuda residential buildings in Medan, located on Jalan Nusantara Medan. This building will be explored through semiotics to assist in appreciating architectural works. It is hoped that this method can answer the semiotic approach in architectural design. The object of research is focused on the part of the building that has the same meaning as the appreciation that he got. This part of the building will be discussed using existing architectural theory so that it can be more clearly understood in its architecture. This research method consists of several stages, namely: (a) The stage of data collection, (b) The stage of adjusting the theory, (c) Data analysis and drawing conclusions. 


\section{Discussions}

The research explains about how the response or appreciation of a building that is named Wisma Garuda Medan, where this building is one of the buildings in the city of Medan that received the Sunyata award. Steps being taken are: (a) Description of Wisma Garuda in Mededan, (b) Discussion of architectural theories related to appreciation of the building of Garuda Garuda in Medan.

\subsection{Description Wisma Garuda in Medan}

Wisma Garuda is a hotel with type budget or reasonably priced rooms located at the intersection of Amaliun road with Nusantara, Medan. The hotel was built in 2012, designed by an architectural firm based in Medan. Based on the results of the interview, the architect accepts the full design assignment or the design of the hotel there is no interference from the owner, except the number of rooms and the price of the building. Wisma Garuda is four stories high and does not have elevators and elevators. Instead it is a single staircase leading directly to the fourth floor but the previous floor is also accessible. The stairs are in the void room which does not have an AC installation. The air feels by the body of the researcher as if flowing. The air flow from the lattice on the outside of the building into the building and centered on voids and then out through the void above and cross ventilation of the building.

Void room lighting can be from sunlight entering through the transparent roof of the voids, so that during the day no electricity is needed. With the extending voids not so wide and limited by the walls of massive rooms, shadows are created so that they do not receive much solar radiation. Stairs can be accessed from the left side of the stairs and the right side only as an aesthetic element (difficult to access) which gives a confusing effect, but access to the top to the fourth floor, researchers do not feel tired. "Because this building does not have an elevator, but aims at how to make people want to go up the stairs voluntarily and stay happy so that it must be made bright and surprising", that's the original purpose of the architect.

Based on interviews from 10 top-floor room tenants, they also felt a confusing and not tiring effect in accessing it, except for tenants over 50 years old. Based on the results of an interview with the Wisma manager, at one time an original wreath was installed in the lobby. Fragrant flowers also smell on the stairwell voids.

In an interview with one of the hotel architects, stated the concept used to design is experience. Where the visual building, interior space and building elements will provide experience for visitors. Researchers get the facts, the hotel has a place in an architecture exhibition in Italy with the theme Sunyata. It is also a fact that architects do not intend to apply Buddhist philosophy to building concepts. This finding is an interesting phenomenon to be examined because the architect's message seems not to be the same as the perception of the exhibition organizers, where the architect applies the concept of experience and observers argue emptiness. 


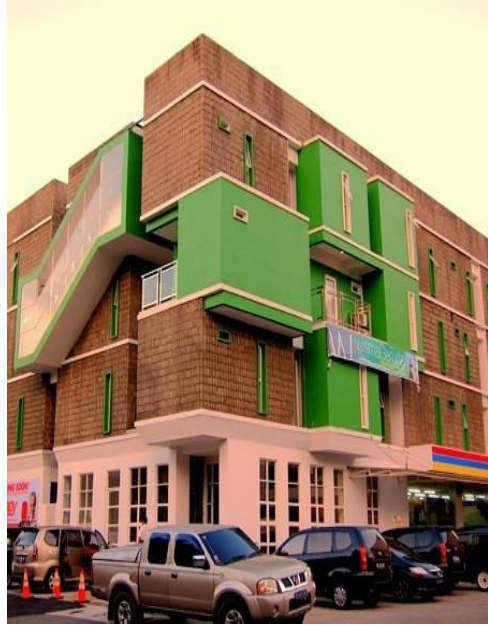

Figure 1. Wisma Garuda

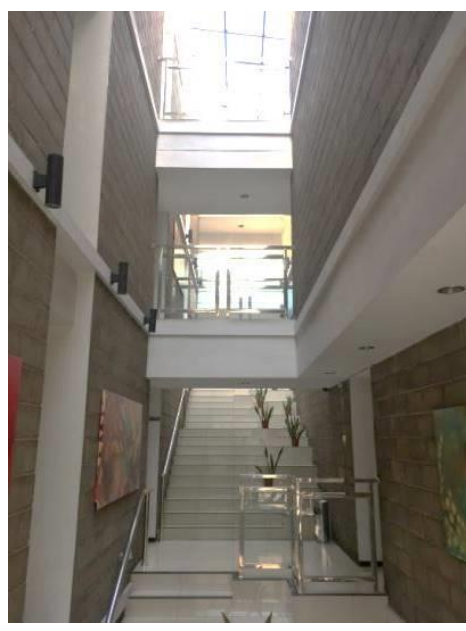

Figure 2. The stairs of the Garuda Medan

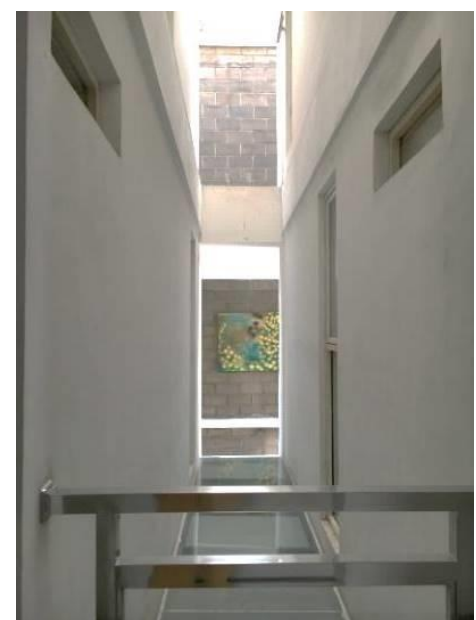

Figure 3. The walls of each room are made separate and hollow.

In Figure it is clear that the design of the stairs uses a skylight, and on the right is designed more playful so as to give a more pleasant impression and can divert fatigue to its users. Void space walls are covered in coarse-textured natural stone. Whereas in Figure 5, it is clear how the design of each wall of the room is made separate and hollow so that the incoming air circulation empties into the staircase as shown in Figure.

\subsection{Experience Analysis}

From the results of interviews and data collection, a concept table can be arranged for the Wisma Garuda building, as shown in table 1.

Table 1. Application of Experience Concepts at Wisma Garuda (analysis)

\begin{tabular}{|l|l|l|}
\hline \multicolumn{1}{|c|}{ Experience } & \multicolumn{1}{|c|}{ Application } & \multicolumn{1}{c|}{ Effect } \\
\hline Hearing & \multicolumn{1}{|c|}{-} & \multicolumn{1}{c|}{-} \\
\hline Vision & $\begin{array}{l}\text { Transparent roofs incorporate } \\
\text { sunlight }\end{array}$ & Does not require lighting \\
\hline Taster & \multicolumn{1}{|c|}{ air } \\
\hline Feeler / taste & $\begin{array}{l}\text { Wall texture not require } \\
\text { Wind flow in voids }\end{array}$ & $\begin{array}{l}\text { Does not } \\
\text { conditioning }\end{array}$ \\
\hline Smell & Placing flowers on voids & Fragrant up to the top floor \\
\hline Mind & Right side stairs & Ambiguous \\
\hline Emotions & Left side stairs, voids & Not tired, surprising \\
\hline
\end{tabular}

\subsection{Analysis of the Relationship between Experience Theory and Emptiness}

The philosophy of cognitive human consciousness is discussed by Husserl related to vision, hearing, smell, taste (tongue), touch and mind [21]. In the study of phenomenology, the philosophy of Husserl's consciousness is very similar to Buddhist philosophy as defined by Vetter [18]. While the state of consciousness is obtained if it has passed the stage of emptiness (void) will get enlightment [16]. Consciousness will generate one's awareness to get experiences like traditional Japanese tea ceremonies based on Buddhist philosophy [17]. 
Based on the analysis, there is a theoretical similarity between Buddha's experience and Husserl's consciousness plus Marleau Ponty's experience regarding the implementation of the concept of Wisma Garuda architecture. It can be concluded that the building is not just emptiness but also experience and support perceived by the organizers of the Indonesian Pavilion 2018 exhibition. The schematic linkage of theoretical analysis can be seen in Figure 4.

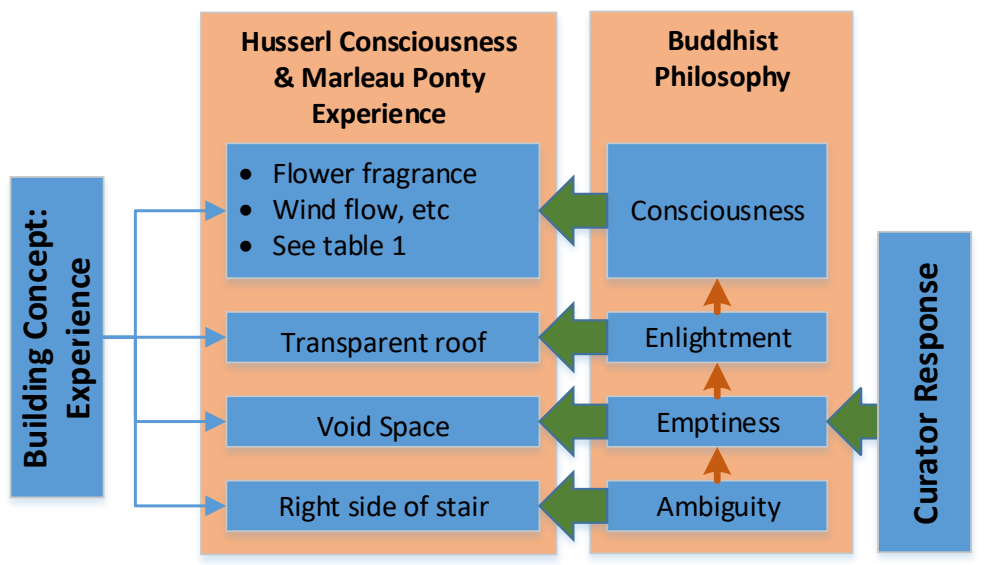

Figure 4. Schematic analysis of the relationship of theory between experience and Buddhist philosophy

\section{Conclusion}

Semiotics is the science of the language of meaning. Architects usually insert meaning into buildings in the form of signs that can be read. In the case of Wisma Garuda, which is a contemporary public building, where it is not specifically related to a particular social culture, the architect applied the concept of experience based on theoretical analysis in fact related to Buddhist philosophy through the views of Husserl and Ponty.

Void space or symbolic Buddhist emptiness turned out to provide a reinforcing effect on the sensory elements of visitors such as the Japanese tea ceremony room. It is this interrelated philosophical theory that is also captured by the curator of the Indonesian Pavilion 2018 as the presence of voidness. Besides that, the fact that the application of experience theory in architecture by an architect who does not use Buddhist philosophical theory, will automatically convey the meaning of a building. In the observations of researchers, Wisma Garuda is not just emptiness (sunyata) but is more towards Buddhist consciousness. At the same time the results of this study prove that reading the meaning that reaches the 2018 Indonesian Pavilion curator is a natural thing.

\section{Acknowledgments}

This article was written based on the implementation of research funded by DIKTI with no. Contract Number: 11 / E1 / KP.PTNBH / 2019, dated March 29, 2019. Thank you to DIKTI and all parties who support the implementation of this research. 


\section{References}

Broadbent, G., \& Jenks, C. (1980) Signs, Symbols and Architecture. New York: John Wiley \& Sons Ltd.

Chappell, D. (2019) 'Contract administration', Construction Contracts, (1997), pp. 65-81. doi: 10.4324/9781315758398-7.

Christensen, Scott M.; Turner, Dale R. (1993). Folk psychology and the philosophy of mind. Routledge. p. xxi. ISBN 978-0-8058-0931-2

Cobley, P \& Jansz, L (2002) Mengenal Semiotika For Beginners, Mizan, Bandung.

Cohen, Richard S. (2006). Beyond Enlightenment: Buddhism, Religion, Modernity. Routledge Taylor and Francis Group. London and New York. ISBN10: 0-415-37294-1.

Eco, U. (1980) Function and Sign: The Semiotics of Architecture. In Sign, Symbol and Architecture. New York: John Wiley \& Sons Ltd.

Gauldie, Sinclair (1969) Architecture (The Appreciation of the Arts/1), General Editor: Harold Osborne Architecture", Oxford University Press, London.

Ghabash, I. (2014) 'The body in modern architecture: Perceptions, philosophies, and design consequences in the work of Le Corbusier and Alvar Aalti', (May 2014). doi: 10.1017/CBO9781107415324.004.

Hale, Jonathan A (2000) Building Ideas - An Introduction to Architectural Theory, John Wiley \& Sons Ltd, England.

Henry K.L, et.al (2013). Sang BUDDHA dan Ajaran-Nya (Ven. Närada Mahäthera, terjemahan). Yayasan Hadaya Vatthu.

Jenks, C. (1980)The Architectural Sign. In Sign, Symbol and Architecture. New York: John Wiley \& Sons Ltd.

Leach, N. (1997) 'Michel Foucault,' in Rethinking Architecture: A Reader in Cultural Theory, Routledge 1997, pp. 329-357

Lebang, Yudha Almeiro Pratama (2017)Analisis Semiotika Simbol Kekuasaan pada Rumah Adat Toraja (Tongkonan Layuk), Prosiding Temu Ilmiah IPLBI 6, Universitas Malikussaleh, Lhokseumawe.

Merleau-Ponty, M. (1962). The Phenomenology of Perception. London: Routledge and Kegan, Paul.

Moleong, L. J. (2004) Metode Kajian Kualitatif. Bandung: Remaja Rosdakarya.

Mouriño, Alexandre (2012). Architecture of Emptiness: Human Flows as Generators of Shapes in Future Architecture. Central for Social Studies - University of Coimbra, Portugal.

Norberg Schulz, C. (1968) 'Intentions in Architecture Christian Norberg-Schulz', The MIT Press.

Norberg-Schulz, Christian (1980) Genius Loci: Towards a Phenomenology of Architecture, Rizzoli University of Michigan.

Pallasmaa, J. (2018) 'Architecture as Experience The fusion of the world and the self', Architectural Research in Finland, 2(1), pp. 9-17.

Pane, I. (2019). The Study of Indisch Architecture Development as an Effort in Preserving the Heritage of Colonial History in Medan. Budapest International Research and Critics Institute (BIRCI-Journal), p 207-214.

Pushpakumara, Saman (2014). Edmund Husserl's Transcendence of Early Buddhist Theory of Consciousness. International Journal of Business and Social Research (IJBSR), Volume -4, No.-3, March, 2014.

Robinson, Richard H. et.al (1997). The Buddhist Religion: A Historical Introduction. Fourth Edition. Wadsworth Publishing Company

Rasmussen, Steen Eiler (1962). Experiencing Architecture. The M.I.T. Press, Cambridge. Second paperback printing, October, 1964.

Robinson, Richard H. et.al (1997). The Buddhist Religion: A Historical Introduction. Fourth Edition. Wadsworth Publishing Company.

Setiadi, David Hutama (2018). Indonesia Pavilion 2018, 16th Internasional Architecture Exhibition of La Biennale, Venezia - Italy. Sunyata: The Poetics of Emptiness. Penerbit: Imaji Media Pustaka.

Sugiyono. (2009) Metoda Penelitian Kualitatif dan Kuantitatif dan R\&D. Bandung: CV. Alfabeta. 
Sheng-Jie, Andrian Hong (2016). The V O I D Architecture: More than just Emptiness. Dissertation, Oxford Brookes University.

Tanaka, Seno (1998). The Tea Ceremony. Kodansha Internasional. ISBN: 4-7700-2507-6.

Tjahyono, Gunawan (1992) Kajian Semiotik Dalam Arsitektur dalam Seminar Semiotik, Jakarta 21-22 Desember 1992, Pusat Penelitian Kemasyarakatan dan Budaya LPUI dan Lingkaran Peminat Semiotik.

Vetter, Tilmann (1988), The Ideas and Meditative Practices of Early Buddhism, BRILL, ISBN 90-0408959-4 